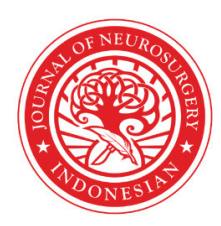

\title{
Greater omental graft transplantation in cranioplasty and duraplasty procedure
}

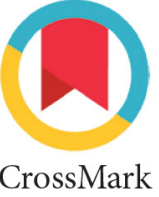

\author{
Richard Axel ${ }^{1 *}$, Yui Prashandika' ${ }^{1}$ Erie Andar², Vega Karlowee ${ }^{3}$, Muhamad Thohar Arifin ${ }^{2}$
}

\section{ABSTRACT}

Introduction: Cranioplasty and duraplasty surgery are standard procedures in brain injury and tumor management. The limited amount of substitution and high cost may lead to a severe problem for those procedures. Hopefully, greater omental contain pluripotent cells which compatible for transplantation procedures. Therefore, the tissue is a potential graft for cranioplasty and duraplasty procedure.

Methods: A post control group design experimental study was conducted for two months. Twelve rabbits (Oryctolagus cuniculus) with two hemisphere regions each were divided randomly into four groups. Six were treated with omental autograft onto cranial bone left side $\left(T_{1}\right)$ and cranial bone with dural tissue $\left(T_{2}\right)$ lesion on the other side. Six other rabbits did not receive any further treatment with cranial bone $\left(C_{1}\right)$ lesion on the left side and cranial bone with dural tissue on the right side $\left(C_{2}\right)$. After two months, the

Keywords: cranioplasty, duraplasty, greater omental graft, tissue repair

Cite This Article: Axel, R., Prashandika, Y., Andar, E., Karlowee, V., Arifin, M.T. 2020. Greater omental graft transplantation in cranioplasty and duraplasty procedure. Indonesian Journal of Neurosurgery 3(3): 92-95. D0I: 10.15562/ijn.v3i3.102 outcome was observed based on the gross and histopathological examinations. The data were analysed with a one-way ANOVA and Post Hoc test.

Results: All rabbits showed no complication based on body temperature and body weight measurement. In the histopathologic examination, we obtained averagely $22.06 \pm 17,91 \mathrm{~mm} 2$, and $9,80 \pm 4,61 \mathrm{~mm} 2$ for the treated group left hemisphere $\left(T_{1}\right)$ and right hemisphere $\left(T_{2}\right)$. For the controlled group, we obtained 3,47 $\pm 2,67$ $\mathrm{mm} 2$ and $1,91 \pm 2,15 \mathrm{~mm} 2$ for left $\left(C_{1}\right)$ and right $\left(C_{2}\right)$ hemisphere consecutively. Both $\mathrm{T}_{1}$ and $\mathrm{T}_{2}$ groups' average tissue repair area was higher than $C_{1}$ and $C_{2}$ groups, respectively.

Conclusion: We founded that greater omental graft was a better substitution to enhance tissue repair in cranioplasty and duraplasty procedures.

\section{INTRODUCTION}

Cranioplastyand duraplasty are common procedures for traumatic brain injury and tumor resection cases. Nowadays, autograft materials, tissue graft potential on the human body, such as pericranium, fascia lata, and temporal fascia, are used for these procedures. $^{1-3}$ Also, synthetic materials indicated for the substitution of the autograft. ${ }^{4}$ However, a limited amount of autograft material on the human body and the high cost of synthetic material will conclude to several problems. Moreover, synthetic material can increase the potential risk of organ rejection on these procedures. ${ }^{4}$

Greater omental tissue is one of the potential substitutions for cranioplasty and duraplasty procedure. Greater omental tissue consists of pluripotent stem cells, also known as AdiposeDerived Stem Cells (ASC/ADSC). ${ }^{5}$ These pluripotent stem cells can differentiate into multilineage embryonic type of cells such as endoderm, mesoderm, and ectoderm cells. ${ }^{5,6}$ The area of greater omental, $300-1500 \mathrm{~cm} 2$, can support the availability of graft material in cranioplasty
Richard Axel; Faculty of Medicine, Diponegoro University, Indonesia; fernandorichard25@gmail.com

Received: 2019-12-14

Accepted: 2020-05-09

Published: 2020-11-19 and duraplasty procedure. $^{7}$ In addition, greater omental tissue contains HOME (Human Omental Microvascular Endothelial) cells, producing fibroblast growth factor for neovascularization and repairment process..$^{8-9}$ Also, Greater omental tissue abilities to adhere to and localize inflamed areas are beneficence for transplantation conditions. ${ }^{8}$

Greater omental graft can be harvested by the laparoscopic procedure. This minimally invasive procedure starts with a standard laparoscopic procedure via the Hasson technique. ${ }^{7}$ It requires a 5 $\mathrm{mm}$ incision on the left upper quadrant side of the abdominal rectus muscle sheath for the insertion of the trocar. Also, the other $10 \mathrm{~mm}$ incision is required for the insertion of the camera trocar on the periumbilical region. After the greater omental tissue is dissected from its adherence, the operator incises the periumbilical region and moves out the dissected omental tissue for transplantation. ${ }^{7,10,11}$

\section{METHOD}

This study has already proven by the institutional ethical committee. In this post control group design 
experimental study, 12 rabbits were divided into two groups (controlled group and treated group) of 6 each. The inclusion criteria were weight of 1.5 $2.5 \mathrm{~kg}$, age 3 to 4 months, and without anatomical abnormalities.

All rabbits were acclimated for a week and underwent a craniectomy procedure approximately $1 \mathrm{~cm} 2$ at each hemisphere. The tissue taken from the left hemisphere was only bone tissue. Besides, the tissue taken from the right one was dura and bone tissue. The treated $(\mathrm{T})$ group was applied with omental autograft with cranioplasty and duraplasty procedure, while the controlled (C) group did not receive any further cranioplasty and duraplasty procedure.

The operation procedure was held under general anesthesia (ketamine $30 \mathrm{mg} / \mathrm{BW}$ IM). In this experiment, an approximately $3-5 \mathrm{~cm} 2$ omental autograft washarvested fromalaparotomy procedure for each treated group, and the temperature (rectal) and body weight were observed weekly for two months. After termination, the lesion from each hemisphere was examined grossly and taken for histopathological analysis. The bone tissue was decalcified with a TBD-1 decalcifier. All tissue was processed for routine Hematoxylin Eosin staining. Each sample was observed for the development of the repair area. The area was then analyzed for width and length using 40x magnification of Leica DM 750 microscope, supported with Leica MC170 HD camera.

\section{RESULT}

During two months of observation, all rabbits were in good condition. The body weight averagely slightly increased, and the body temperature was all in normal range $\left(38-39,9^{\circ} \mathrm{C}\right)$ until termination. In gross examination, no local infection found in both skin incision and lesion area. The lesion was

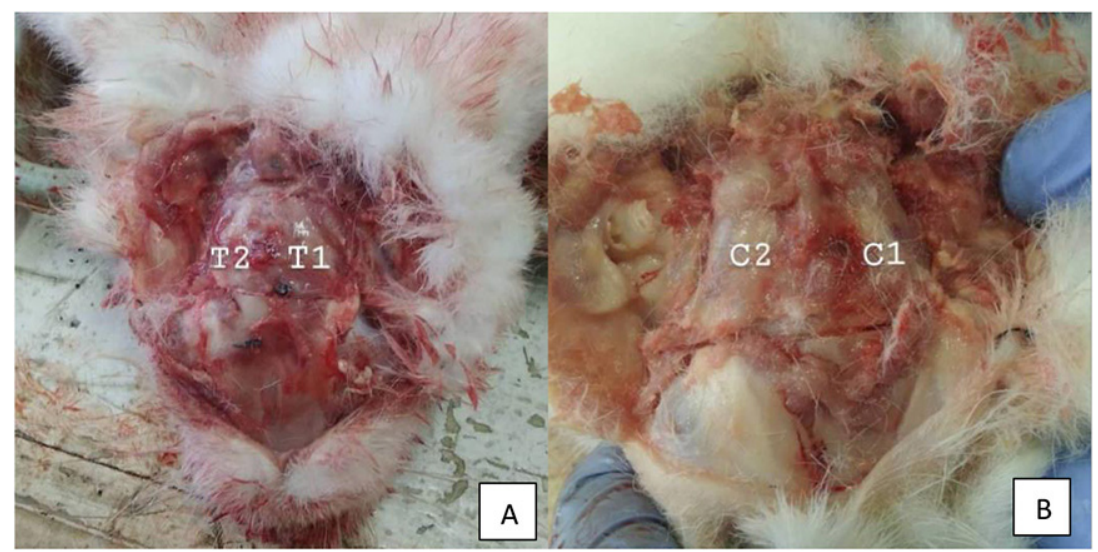

Figure 1. Macroscopic view after surgery procedure of transplanted group (A) and controlled group (B) healed completely in all groups. There was no remarkable finding between each group (Figure 1). For histopathologic samples, we obtained averagely $22.06 \pm 17,91 \mathrm{~mm}^{2}$ and $9,80 \pm 4,61 \mathrm{~mm}^{2}$ for the treated group left hemisphere $\left(\mathrm{T}_{1}\right)$ and right hemisphere $\left(\mathrm{T}_{2}\right)$. For the controlled group, we obtained $3,47 \pm 2,67 \mathrm{~mm}^{2}$ and $1,91 \pm 2,15 \mathrm{~mm}^{2}$ for left $\left(\mathrm{C}_{1}\right)$ and right $\left(\mathrm{C}_{2}\right)$ hemisphere consecutively. The data of the repair area (Figure 2) from each group were listed in Table 1.

All data were analyzed with the Shapiro-Wilk normality test and were normally distributed $(p>0,05)$. Then, One-way ANOVA and Post Hoc tests were used to compare each group $\left(T_{1}\right.$ with $T_{2}$ and $\mathrm{C}_{1}$ with $\mathrm{C}_{2}$ ). Post Hoc test showed there was no significant $\mathrm{p}$-value between both treated and controlled groups. However, a significant p-value was attained between the overall treated and controlled group.

\section{DISCUSSION}

Based on two months of body weight and temperature observation, all rabbits were in good condition after the procedure. The body temperature of every group remained stable in the normal range $\left(38,1-40,8{ }^{\circ} \mathrm{C}\right)$. (12) Also, bodyweight increased every week. In addition, there was no sign of hemorrhage, infection, excessive scar formation, irritation, and rejection. This result supported Turchan et al., and Liu et al., in regard to use autologous graft for transplantation, would not induce a systemic immune response, reducing the rejection and systemic disturbance risk. $(1,13)$

The omental autograft transplantation procedure may have a role in this study procedure. The $T_{1}$ group showed the highest mean area of tissue repair, followed by the $\mathrm{T}_{2}$ group, $\mathrm{C}_{1}$ group, and lastly $\mathrm{C}_{2}$ group. The tissue repair mean area in the transplanted groups was higher in the controlled groups.

The bone regeneration process is divided into four stages: Initial inflammatory response, soft callus formation, hard callus formation, and bone remodeling. (14) In this study, considering that the $\mathrm{C}_{1}$ group showed the bone remodeling process. In this stage, osteoblast and osteoclast are involved in the formation of new bone tissue. (14) In addition, these cells were activated, resulting from TGF- $\beta$ and BMP-2 cytokines release by osteoprogenitor cells. $(15,16)$ While in the $\mathrm{C}_{2}$ group, where the dural tissue was taken, the dural healing was also taking a part of the repairing process in the lesion site. Lear and Harvey (17) suggest that the dural tissue healing consists of thickened process, fibroblast invasion, and organization of fibrous structure for 7 to 40 days. We suggest that the bone and the dural 
Table 1. Mean area of tissue repair

\begin{tabular}{cccccc}
\hline \multirow{2}{*}{ Groups } & $\mathbf{n}$ & Normality test & Post-test $\left(\mathbf{m m}^{2}\right)$ & \multicolumn{2}{c}{$\mathbf{p}$} \\
\cline { 3 - 6 } & & 6,114 & $22.06 \pm 17,91$ & 0,515 & \\
$\mathrm{~T} 1$ & 6 & 0,950 & $9,80 \pm 4,61$ & & $0,015^{*}$ \\
$\mathrm{~T} 2$ & 6 & 0,231 & $3,47 \pm 2,67$ & & \\
$\mathrm{C} 1$ & 6 & 0,161 & $1,91 \pm 2,15$ & & \\
$\mathrm{C} 2$ & 6 & &
\end{tabular}

${ }^{\star}$ One-way ANOVA

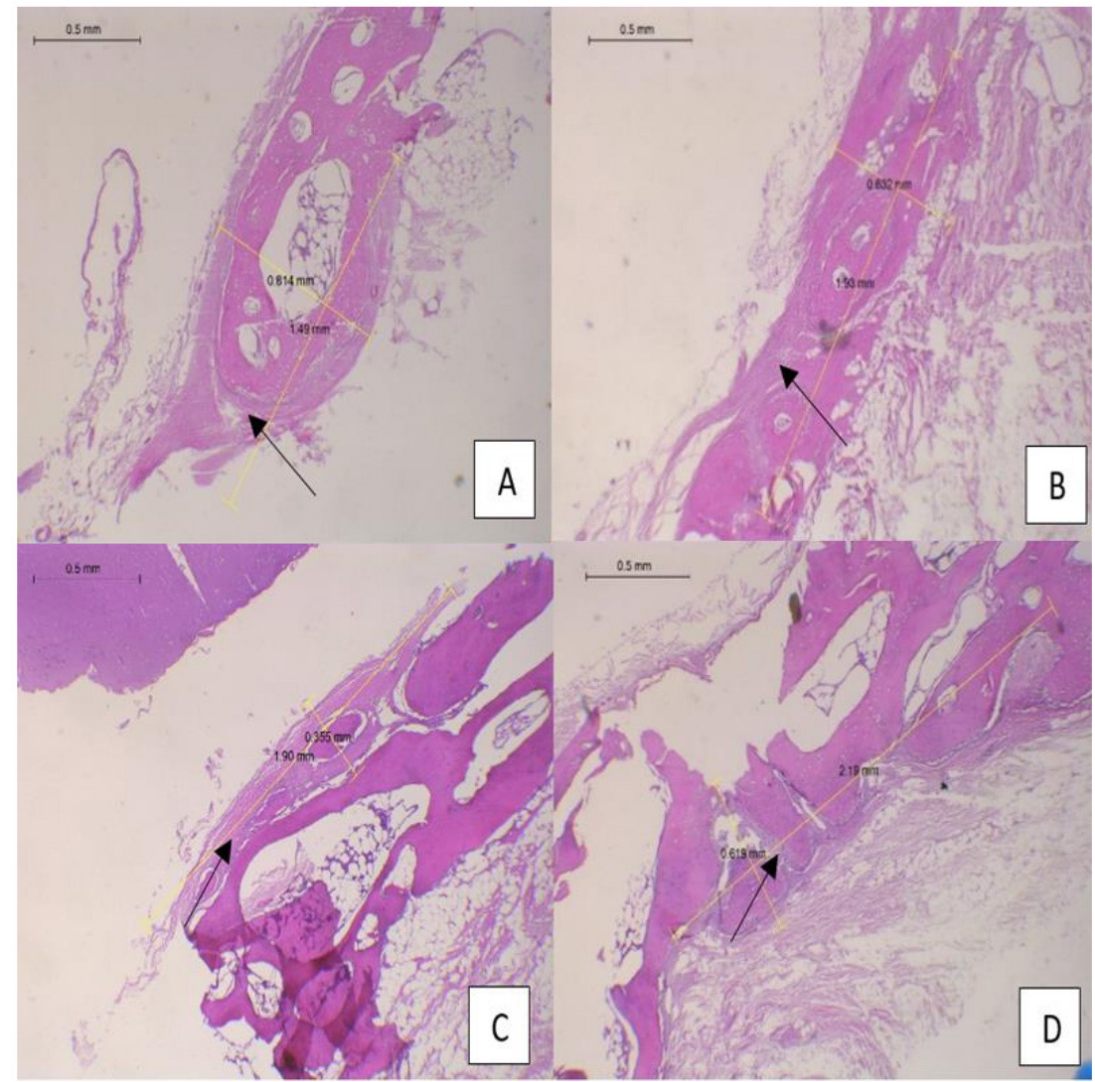

Figure 2. Histopathological findings with Hematoxylin Eosin staining of the transplanted and controlled group (40x): T1 (A) and T2 (B), C1 (C) and C2 (D); Arrow = tissue repair

tissue healing process was happened simultaneously, resulting in the smaller repair area in the $\mathrm{C}_{2}$ group than the $\mathrm{C}_{1}$ group.

Omental autograft, mainly consist of adipocyte cells, contain ASC that have a role in regeneration and tissue repair. ${ }^{18,19}$ Fibroblast, differentiated from ASC, migrated and proliferated to the injured area, release extracellular matrix for the remodeling process. ${ }^{20-21}$ Also, omental graft contains immunological cells such as macrophages, B-lymphocytes, T-lymphocytes, mast cells, and stromal cells that enhance inflammation process. ${ }^{8,15,18,22}$ In addition, omental graft promotes the angiogenesis process due to the promotion of collagen synthesize and cytokine release from adjacent cells. ${ }^{20,21,23}$ In regard to this study, the treated groups showed a higher repair area, then the controlled groups. We suggest that the bone and dural tissue healing process in the treated group happened simultaneously. In fact, the $\mathrm{T}_{1}$ group tissue repair area was higher than $\mathrm{T}_{2}$.

\section{CONCLUSION}

In this study, the long duration of the study was expressed a nearly complete healing process, resulting in the identification between the lesion and healthy tissue area was hard to differentiate. Also, the cytokine examination was excluded from this study. Besides, we suggest that omental graft transplantation can be used as an alternative substance in cranioplasty and duraplasty procedure. We found that omental autograft transplantation is beneficial that there was no complication and rejection sign. The omental autograft also potentially increases the tissue repair and regeneration process by increasing the area of the new connective tissue.

\section{ACKNOWLEDGEMENTS}

This paper would not be completed without support from my family, neurosurgery department faculty of medicine, Diponegoro University, neurosurgery residents of neurosurgery department faculty of medicine, Diponegoro University, anatomy laboratory assistants' faculty of medicine, Diponegoro University, and many people whose cannot be mention one by one.

\section{CONFLICT OF INTEREST}

There is no conflict of interest related to the materials or method in this study

\section{FUNDING}

This study received no specific funding from any funding agency

\section{AUTHOR'S CONTRIBUTION}

Author, YP, EA, and VK took part in experimental design study and data collection. Also, Author and YP did literature review and article drafted. EA, VK, and MTA made a critical revision and suggestion for the article. All agree to accept equal responsibility for the manuscript contents.

\section{REFERENCE}

1. Turchan A, Rochman TF, Ibrahim A, Fauziah D, Wahyuhadi J, Parenrengi MA, et al. Duraplasty using amniotic membrane versus temporal muscle fascia: A 
clinical comparative study. J Clin Neurosci [Internet]. 2018;50:272-6. Available from: https://doi.org/10.1016/j. jocn.2018.01.069

2. Chaaban MR, Illing E, Riley KO, Woodworth BA. Spontaneous cerebrospinal fluid leak repair: A five-year prospective evaluation. Laryngoscope. 2014;124(1):70-5.

3. Wormald PJ, Alun-Jones T. Anatomy of the temporalis fascia. J Laryngol Otol [Internet]. 1991 Jul 29 [cited 2019 Feb 21];105(07):522-4. Available from: http://www. journals.cambridge.org/abstract_S0022215100116500

4. MacEwan MR, Kovacs T, Osbun J, Ray WZ. Comparative analysis of a fully-synthetic nanofabricated dura substitute and bovine collagen dura substitute in a large animal model of dural repair. Interdiscip Neurosurg Adv Tech Case Manag [Internet]. 2018;13(March):145-50. Available from: https://doi.org/10.1016/j.inat.2018.05.001

5. The Editors of Encyclopaedia Britannica. Adipose Tissue. Encyclopædia Britannica, inc [Internet]. 2018 Nov; Available from: https://www.britannica.com/science/ adipose-tissue

6. Liao H-T. Osteogenic potential: Comparison between bone marrow and adipose-derived mesenchymal stem cells. World J Stem Cells. 2014;6(3):288.

7. Costantino PD, Shamouelian D, Tham T, Andrews R, Dec W. The Laparoscopically Harvested Omental Free Flap: A Compelling Option for Craniofacial and Cranial Base Reconstruction. J Neurol Surgery, Part B Skull Base. 2017;78(2):191-6.

8. Hertzler AE. The omentum. J Am Med Assoc. 1926;86(23):1785.

9. Lowery E, Byrne K, Seki Y, Huang N, Takami M, Wigfield $\mathrm{C}$, et al. Cellular Basis of Tissue Regeneration by Omentum. PLoS One. 2012;7(6):e38368.

10. Salameh JR, Chock DA, Gonzalez JJ, Koneru S, Glass JL, Franklin Jr. ME. Laparoscopic harvest of omental flaps for reconstruction of complex mediastinal wounds. JSLS. 2003;7(1086-8089; 4):317-22.

11. Vyas RM, Prsic A, Orgill DP. Transdiaphragmatic omental harvest: A simple, efficient method for sternal wound coverage. Plast Reconstr Surg. 2013;131(3):544-52.
12. Chen PH, White CE. Comparison of Rectal, Microchip Transponder, and Infrared Thermometry Techniques for Obtaining Body Temperature in the Laboratory Rabbit ( Oryctolagus cuniculus ). 2006;45(1):57-63.

13. Liu G, Zhang Y, Liu B, Sun J, Li W, Cui L. Bone regeneration in a canine cranial model using allogeneic adipose derived stem cells and coral scaffold. Biomaterials [Internet]. 2013;34(11):2655-64. Available from: http://dx.doi. org/10.1016/j.biomaterials.2013.01.004

14. Rammelt S. Comprehensive histological evaluation of bone implants. Biomatter. 2014;4(June 2015):37-41.

15. Krafts KP. Tissue Repair. 2010;(December):225-33.

16. Rahman S. Proses Penyembuhan Fraktur. J Orthop FK Unsyah. 2014;266-86.

17. Lear M, Harvey $\mathrm{S}$. The regeneration of the meninges by maxwell lear, m.d. :536-44.

18. Ciuffi S. Adipose stem cells for bone tissue repair. Clin Cases Miner Bone Metab. 2017;14(2):217.

19. Mescher AL. Junqueira's Basic Histology. 12th ed. New York: Mc Grawhill;

20. Sumbayak EM. Fibroblas: Struktur dan Peranannya dalam Penyembuhan Luka. 2018;(6). Available from: http://ejournal.ukrida.ac.id/ojs/index.php/Ked/article/ viewFile/1169/1409

21. Wideman TH, Zautra AJ, Edwards RR. Fibroblast and Myofibroblast in Wound Healing: Force generation and Measurement. 2014;154(11):2262-5.

22. Meza-Perez S, Randall TD. Immunological Functions of the Omentum. Trends Immunol [Internet]. 2017 Jul [cited 2019 Feb 26];38(7):526-36. Available from: https:// linkinghub.elsevier.com/retrieve/pii/S1471490617300522

23. Mizuno H, Tobita M, Ogawa R, Orbay H, Fujimura J, Ono S, et al. Adipose-Derived Stem Cells in Regenerative Medicine. Princ Gender-Specific Med Gend Genomic Era Third Ed. 2017;459-79.

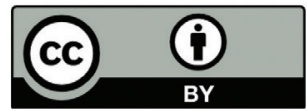

This work is licensed under a Creative Commons Attribution 